\title{
Lipometabolic side-effects of three ritonavir-boosted double protease inhibitor regimens without reverse transcriptase inhibitors
}

\author{
A Wendig1, C Stephan*1, P Khaykin ${ }^{1}$, M Bickel ${ }^{1}$, T Lennemann ${ }^{1}$, G Knecht ${ }^{2}$, \\ T Lutz ${ }^{2}, \mathrm{~N}$ von Hentig ${ }^{1}$ and S Staszewski ${ }^{1}$
}

Address: ${ }^{1}$ University Hospital Frankfurt - HIVCENTER, Frankfurt, Germany and ${ }^{2}$ Infektiologikum, Frankfurt, Germany

* Corresponding author

from Ninth International Congress on Drug Therapy in HIV Infection

Glasgow, UK. 9-13 November 2008

Published: 10 November 2008

Journal of the International AIDS Society 2008, I I (SuppI I):PI 22 doi:I0.II86/I758-2652-I I-SI-PI 22

This abstract is available from: http://www.jiasociety.org/content/I I/SI/PI22

(c) 2008 Wendig et al; licensee BioMed Central Ltd.

\section{Purpose of the study}

To compare the lipometabolic profiles of three doubleboosted protease inhibitor (PI) regimens at standard dose, containing saquinavir and ritonavir in combination with lopinavir (LOPSAQ), atazanavir (ATSAQ) or fosamprenavir (FOSAQ) in HIV-positive patients, treated without reverse transcriptase inhibitors (RTI).

\section{Methods}

Comparative cohort analysis on 173 patients receiving LOPSAQ, ATSAQ or FOSAQ as only antiretroviral therapy (ART). Total cholesterol and triglycerides were measured at baseline (BL) and in the course over 48 weeks after initiation of a ritonavir-boosted double PI regimen. Highdensity-lipoprotein (HDL) and low-density-lipoprotein (LDL) were measured after an overnight fast.

\section{Summary of results}

Median baseline characteristics were a patient age of 42 years, male gender $(\mathrm{n}=139 ; 80.4 \%)$ and 10.1 years from first HIV-positive test. 158 patients were ART-experienced and received a boosted double PI regimen due to previous RTI-resistance and/or toxicity. Among these, 68 patients previously had a structured treatment interruption and 90 patients have been treated with a PI-sparing ART regimen; 15 patients were ART-naïve. Differences for metabolic parameters between groups were not significant. Fiftyeight out of 173 patients received a lipid-lowering agent (LLA) (LOPSAQ $\mathrm{n}=42$, ATSAQ $\mathrm{n}=11$, FOSAQ $\mathrm{n}=5$ ) and seven (4\%) were initiated on a new LLA during the study. Total cholesterol significantly increased over 48 weeks for all groups: $166 \mathrm{mg} / \mathrm{dL}$ to $213 \mathrm{mg} / \mathrm{dL}$ (LOPSAQ), $168 \mathrm{mg} /$ $\mathrm{dL}$ to $216 \mathrm{mg} / \mathrm{dL}$ (ATSAQ) and $161 \mathrm{mg} / \mathrm{dl}$ to $235 \mathrm{mg} / \mathrm{dl}$ (FOSAQ) after 48 weeks (for all, $\mathrm{p}<0.01$; ITT-analysis), whereas median triglyceride levels significantly increased only for the LOPSAQ-group (195 mg/dl to $283 \mathrm{mg} / \mathrm{dl}$; p < 0.01 ), but not for the other two groups (ATSAQ: $161 \mathrm{mg} /$ $\mathrm{dL}$ to $202 \mathrm{mg} / \mathrm{dL}, \mathrm{p}=0.2$; FOSAQ: $130 \mathrm{mg} / \mathrm{dl}$ to $220 \mathrm{mg} /$ $\mathrm{dl}, \mathrm{p}=0.6)$. HDL- and LDL-cholesterol increased non-significantly in all groups. See Figure 1.

\section{Conclusion}

After 48 weeks on a double-boosted PI regimen, all three patient groups showed significant increases in total cholesterol. The increase in triglyceride levels was only significant for LOPSAQ, but not for ATSAQ or FOSAQ. Overall, $<5 \%$ required a new LLA-therapy during the first 48 weeks. HDL- and LDL-cholesterol increases were not significant. The cardiovascular impact of these lipometabolic interferences requires further investigations. 

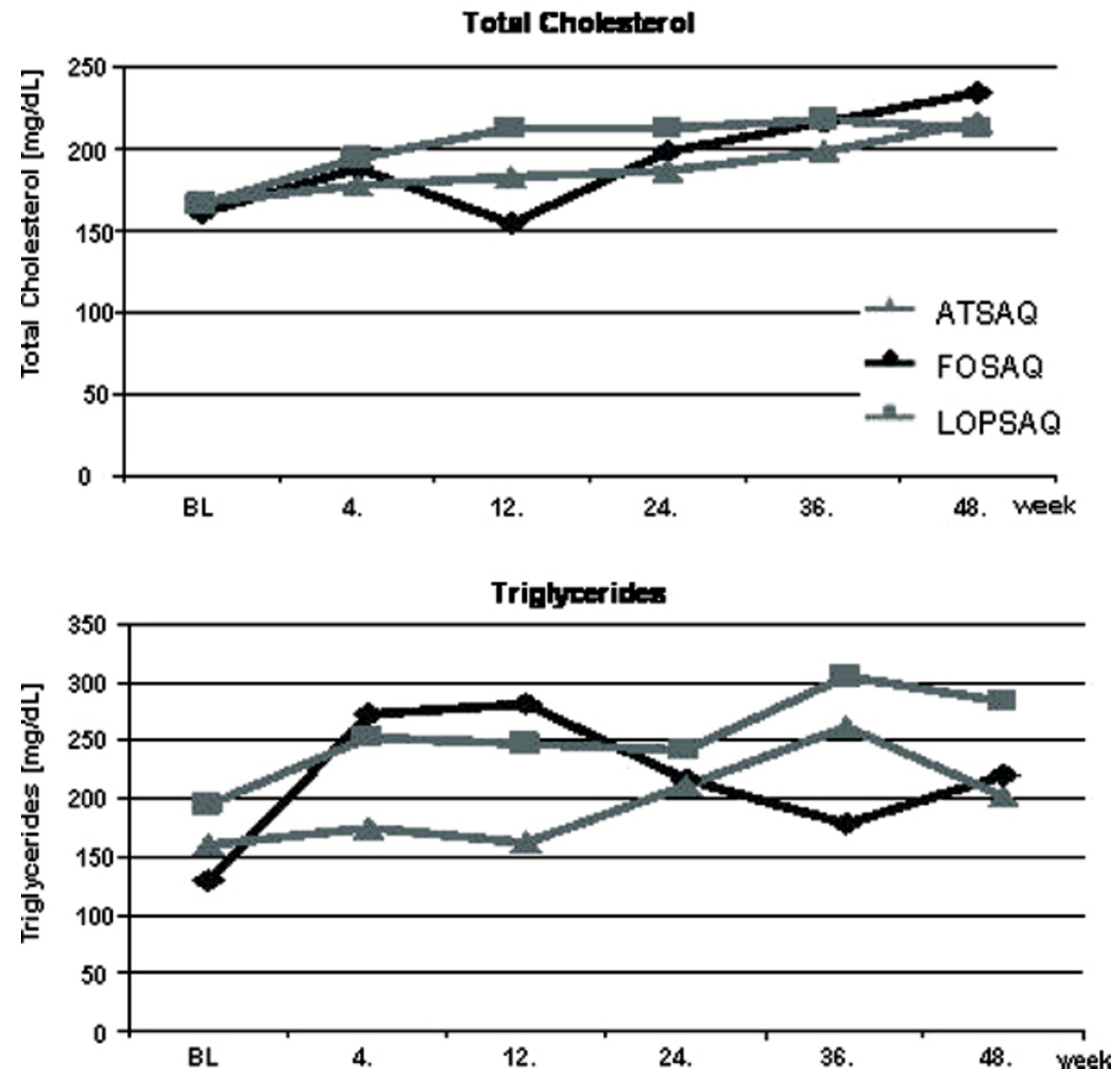

Figure I

Serum total cholesterol and triglycerides of three double boosted protease inhibitor regimens over 48 weeks.

Publish with Biomed Central and every scientist can read your work free of charge

"BioMed Central will be the most significant development for disseminating the results of biomedical research in our lifetime. "

Sir Paul Nurse, Cancer Research UK

Your research papers will be:

- available free of charge to the entire biomedical community

- peer reviewed and published immediately upon acceptance

- cited in PubMed and archived on PubMed Central

- yours - you keep the copyright
BioMedcentral 